\title{
Remaining Challenges
}

\author{
Landwirtschaft und Umwelt gehörten beide zu den schwierigeren Themen der \\ Beitrittsverhandlungen. Stellen schon die allgemeinen Umweltschutzanforde- \\ rungen der EU eine Herausforderung für die Beitrittsstaaten dar, so gilt dies in \\ besonderem Maße für die Schnittstelle zwischen Landwirtschaft und Umwelt. Die \\ Unterstützungsprogramme der EU wie etwa SAPARD spielten hier eine ambiva- \\ lente Rolle. Wesentliche Herausforderungen liegen noch vor der erweiterten EU.
}

$\mathrm{T}$ he eastward enlargement con Anett Zellei both the accession countries and the $\mathrm{EU}$ with unique and unprecedented challenges. An EU funded research project on Sustainable Agricultural Development in the Central and Eastern European Countries in which I have been involved has revealed some of these difficulties (1). The investigation of the development of agri-environmental policy in six accession countries has been conducted through case studies, studying the implementation of the Nitrate, Habitats and Birds Directives. These studies have identified the following issues.

\section{- The Environment as Major Nego- tiation Topic}

Negotiation on the environmental acquis became a major issue for the current accession countries, unlike during the integration of the Southern European States. Since the accession of the Mediterranean countries, environmental policy making has become more ambitious and the scope and depth of environmental legislation has increased enormously.

Lessons from the Southern enlargement, when delayed awareness of many unsolved environmental problems and difficulties with implementation imposed considerable costs on the Community through the Structural and Cohesion Funds, lead to a modified EU strategy for the current accession countries. Existing Member States are not keen on allowing an environmental gap to continue for a long time after accession as it would distort internal competition. For these reasons the $\mathrm{EU}$ has been emphasising that applicant countries should go beyond the formal transposition of the environmental acquis and establish effective administrative practices as well as concrete plans for practical implementation and financing. To date the Com- mission has managed to keep a strict negotiating position on the environment chapter, not allowing any transition periods on horizontal regulations, or any nature protection legislation. Accession countries mainly require derogation for ,,investmentheavy" directives which are demanding in either financial or administrative terms.

Although compared to previous cases, the environmental acquis gained more significance in the negotiation process, it has not been a major stumbling block. Agriculture and internal market related issues are the priority determinants of the process.

\section{- Centralised Capacity Building}

Certainly, one of the impacts of the EU integration process on the accession countries is an immense centralised institution and capacity building. The EU accession process pushes the applicant countries towards greater convergence with particular institutional models than has occurred within the existing EU. National elites in the accession countries have been open to these models to a certain degree. However, they have limited possibilities to mitigate the EU influence. As accession is conditioned to the transposition of a great deal of legislation and procedural rules by the accession countries, the process seems to be rather top-down in nature, reflecting an asymmetric policy relationship between the parties. The whole accession process has an executive bias because of the structure of negotiations and the fact that $\mathrm{EU}$ actors mostly see the process of adopting EU norms as a legal-administrative exercise. By emphasising capacity building at the central level, the EU integration reinforces the tendency towards a core executive at the expense of other branches and levels of government. This is unfortunate given that most of the Central and Eastern European Countries (CEECs) have a background of weak local and regional structures.
Effective implementation and enforcement of $\mathrm{EU}$ environmental policy will require the development of national and sub-national institutions with well trained and managed public administrations and the strengthening of civil society. Although the Commission has been constantly emphasising that accession countries should strengthen their capacity and institutional ability at both regional and local levels, it does not provide a detailed institutional preference. This might be a difficult and politically sensitive task, especially given that administrative systems remain so diverse in the current Member States.

The EU has been facilitating capacity building necessary to implement the acquis in the CEECs through its Phare and twinning programme. However, the impact of the twinning programme on CEE administration is likely to be diffuse as advice offered by civil servants from Member States is not controlled centrally by the EU. It focuses on standards and technical issues rather than overall institutional models.

The effective implementation of EU environmental policy will require higher environmental awareness and commitment not only from national governments but the applicant countries' general publics. A shift from the short-sighted and wasteful attitude of exploiting natural resources inculcated during the socialist era, requires massive education and training. The flexible approach urged by the EU environmental directives represents a novelty for CEEC regulators and inspectors as they are used to deal with precisely detailed legislation with limited possibility for discretionary action. Their work has become more complex and difficult due to the land reform and privatisation programmes which have increased the number of farm holdings and created an extremely diverse set of actors in rural areas with contrasting farm sizes and levels of education.

\section{Dealing with Compliance Costs}

From the applicant countries' point of view the pursuit of high environmental standards is difficult to accept during times of economic stress. The compliance cost of the 10 CEECs to harmonise with the full environmental acquis have been estimated between 79 and 110 billion Euro exclusive of legislation adopted in 2000 and expected in 2001. It is difficult to envisage how the costs of environmental improvements on farms required for EU harmonisation will be achieved in some accession countries which are characterised by small scale production and low agricultural returns. 
The EU has been providing pre-accession funds for environmental investments in the accession countries through its Phare, SAPARD and ISPA instruments (see the contribution by Allgayer), amounting to 3 billion Euro annually over the period 2000-2006. Resources allocated by SAPARD for the modernisation of agriculture and rural development have been moderate given the significant changes in agricultural and rural conditions that are required. Within the accession countries the primary focus of SAPARD is on the establishment of adequate agencies and systems of implementation. Therefore it is more a preparatory measure rather than a forerunner of the Rural Development Regulation.

\section{- Neglected Environment}

In all CEECs considerable amounts of domestic resources have been invested into establishing the structures to implement SAPARD, in advance of any expenditure of EU funds. Disappointments have arisen not only over the delay and emphasis on building up appropriate structures - delaying accreditation of SAPARD Paying and Implementing Agency - but also on the complex procedure and heavy regulatory demand. The agri-environment is a very minor component of the SAPARD programme and the funds devoted to it are modest regarding the needs in the accession countries. Indeed future member States placed priority on „classic“ agricultural activities, structural adjustments, investment for processing and marketing and delayed the implementation of the agri-environmental measures. The agri-environment schemes incorporate an entirely new concept requiring a complex administration, which is rather unfamiliar for the majority of staff in the accession countries. Therefore any

\begin{tabular}{|c|}
\hline Nachbaltige \\
Finanzmärkte? \\
und \\
Geteilte Verantwortung \\
für den \\
Verbraucherschutz \\
sind die Themen \\
der Informationsdienste \\
Ökologisches Wirtschaften \\
2/03 und 3-4/03 \\
Wenn Sie potenzielle Beiträge haben, \\
wenden Sie sich bitte \\
an die Redaktion.
\end{tabular}

delay with this instrument might risk that CEECs miss the opportunity to gain essential experience in developing and running pilot agri-environmental schemes prior to accession. The lack of convincing agri-environment measures upon accession might delay the approval of the CEECs' Rural Development Regulation given that agri-environment is a compulsory component of it and consequently limits access to relevant funding.

In general pre-accession funds are not effectively linked to the implementation of key EU Directives (e.g. Habitats and Nitrate Directives). These instruments usually favour the bigger and production oriented farmers. Small agricultural operators are often discouraged to apply for these grants due to the complex application procedure and the lack of required own resources. Accession countries can apply for the LIFE-Nature programme, which is especially geared for the establishment of the Natura 2000 ecological network. Nevertheless, this instrument, like the pre-accession funds, is only co-financed by the EU and the provision of domestic resources is often a hurdle for the CEECs.

It is feared that the lack of economic resources facilitating the effective implementation of EU directives and the adaptation pressure imposed on domestic institutional structures can result in an incomplete and ambiguous implementation in the accession countries. Eastern enlargement might slow down the implementation of the present environmental acquis and the decision-making process due to different policy preferences. This might exacerbate the implementation deficit of $\mathrm{EU}$ environmental policy, which is already a considerable problem in existing member states.

\section{Agri-environmental Perspectives}

There is a widespread perception amongst relevant national actors in the CEECs that EU integration is acting as a catalyst for the development of agri-environmental policy. However, accession states constitute a diverse socio-political and economic group, which differ in their environmental performance, administrative capacity and financial inflows. Current EU policies may not necessarily provide the most efficient solutions to agri-environmental problems given the different needs and priorities, economic and ecological situations between the Western and Eastern European countries. These specific characteristics should be taken into account during the development of EU policy.

It is likely that EU accession will result in areas of intensively driven agricultural production contrasting with abandoned areas in less favourable regions. Both processes may lead to a loss of biodiversity. Land abandonment, which is already a serious and large-scale problem in the CEECs, especially pose a threat to the marginal, extensive areas of valuable semi-natural grasslands. Restricting livestock quotas to current levels - which already represents a massive decline in gazing livestock throughout the region - would create a problem from an environmental management point of view on these regions of high biodiversity. Such areas should receive more attention in the Community instruments targeting nature conservation in extensively driven agricultural areas. A carefully designed and balanced mixture of policy instruments should be provided to the accession countries. These should be designed partly to limit environmental damage resulting from anticipated agricultural intensification and partly to counter potential loss implied by structural change in agricultural and rural areas following accession. This calls for the development of non-farm rural economies, diversification and establishment of appropriate agri-environment measures. A wider range of policy tools is required in which agri-environmental policy should not be seen merely as a constraint on farming practices but rather a central part of a more positive framework for rural development. Nevertheless to date current enlargement process gives accession countries limited chance to improve the living conditions in rural areas apart from modernisation of the farming sector, intensification of agriculture and improvements in infrastructure.

\section{Reference}

(1) Zellei, A./ Gorton, M./ Lowe, P.: Agri-environmental Policy Systems in Transition: Problems and Perspectives. In: Gatzweiler, F./ Hagedorn, K./ Judis, R. (Hrsg.): Sustainable Agriculture in Central and Eastern European Countries: The Environmental Effects of Transition and Needs for Change. Proceedings of the ACE Phare Seminar, Aachen 2002. Siehe auch die Projektwebsite www.ceesa.de

\section{Die Autorin}

Anett Zellei ist nach einem agrarökonomischen Studium in Debrecen, Ungarn, und einer Tätigkeit beim Sekretariat der Ramsar Konvention zurzeit wissenschaftliche Mitarbeiterin an der Universität Newcastle. Kontakt: Centre for Rural Economy, University of Newcastle upon Tyne, Tel. 0044-191-222-8608, Fax -5411, E-Mail: anett.zellei@ncl.ac.uk 
(c) 20I0 Authors; licensee IÖW and oekom verlag. This is an article distributed under the terms of the Creative Commons Attribution Non-Commercial No Derivates License (http://creativecommons.org/licenses/by-nc-nd/3.o/), which permits unrestricted use, distribution, and reproduction in any medium, provided the original work is properly cited. 